\title{
A new method for quantification of aortic stiffness in vivo using magnetic resonance elastography (MRE): a translational study from sequence design to implementation in patients
}

\author{
Rachel Clough*, Ondrej Holub, Henry Fok, Nicholas Gaddum, Jordi Alastruey, Ralph Sinkus
}

From 18th Annual SCMR Scientific Sessions

Nice, France. 4-7 February 2015

\section{Background}

Aortic stiffness is an important risk factor in the development of cardiovascular disease. Early detection of stiffening is important so that appropriate medical and behavioural interventions can be implemented. Applanation tonometry pulse wave velocity is the current non-invasive reference standard but this only provides spatially-averaged measurements. Local measurements may be more important, particularly in the ascending aorta due to aorto-ventricular coupling effects. MRE usually requires a surface transducer to generate shear waves in the tissues but these are expensive, uncomfortable and not available in all centres.

The aim of this study was to develop a new transducer-free MRE sequence to measure aortic stiffness in vivo using aortic valve closure, an intrinsic source for elastography, to generate shear waves in the aortic wall.

\section{Methods}

This study has 4 parts: sequence development (pulse programming and simulations) and implementation on a clinical 3T MR scanner; validation of MRE measurements in (a)simple geometry and (b)aortic phantoms; a volunteer study $(\mathrm{n}=8)$ to assess cardiac and respiratory motion compensation strategies and the sensitivity of the motion-encoding gradients; and a patient study (hypertensive patients, $\mathrm{n}=15$ ) to compare MRE and other MR methods (QA Loop; transit-time (TT)) for measurement of aortic stiffness to the current non-invasive reference standard applanation tonometry.

King's College London, London, UK 


\section{Funding}

BHF/Wellcome Trust/MRC/AMS.

Published: 3 February 2015

doi:10.1186/1532-429X-17-S1-042

Cite this article as: Clough et al:. A new method for quantification of aortic stiffness in vivo using magnetic resonance elastography (MRE): a translational study from sequence design to implementation in patients. Journal of Cardiovascular Magnetic Resonance 2015 17(Suppl 1): O42.

Submit your next manuscript to BioMed Central and take full advantage of:

- Convenient online submission

- Thorough peer review

- No space constraints or color figure charges

- Immediate publication on acceptance

- Inclusion in PubMed, CAS, Scopus and Google Scholar

- Research which is freely available for redistribution 